\title{
An Analysis of Z-Scores \& Performance: Manufacturing Companies in Hong Kong
}

\author{
Foo See Liang ${ }^{1 *}$ and Shaakalya Pathak ${ }^{2}$ \\ ${ }^{1}$ Practice Associate Professor of Accounting \\ School of Accountancy, Singapore Management University, Singapore 188065 \\ ${ }^{2}$ Research Assistant and Bachelor of Accountancy Candidate \\ School of Accountancy, Singapore Management University, Singapore 188065 \\ *Corresponding author's email: slfoo [AT] smu.edu.sg
}

\begin{abstract}
Hong Kong is a key leading economy in the Asia Pacific region. This study examines the relationship between the financial health, as measured by the Altman Z-Score, and corporate performance, as measured by the Return on Equity (ROE), of listed manufacturing companies in this market. A linear regression has been conducted between these variables to determine the magnitude and direction of their relationships. The trends of Z-Scores over a five-year period have also been analysed. The analysis covers the period from 2013 to 2017 (inclusive) and yields a statistically positive correlation between ROE and the Z-Score for the market. Hong Kong registered relatively healthy mean and median Z-Scores. These findings further support the strong economic position of this market as an Asian giant.
\end{abstract}

Keywords - financial health, corporate performance, manufacturing, altman z-score, roe, hong kong, hkse, sehk

\section{INTRODUCTION}

\subsection{Introducing the Research Topic}

The Asia Pacific region has experienced dramatic economic growth in recent years (IMF, 2017). While growth is essential, the sustainability of organizations is also dependent on its financial health. A notable important economy that is riding on these economic growth trends is Hong Kong. This economy is an important business hub in the Asia Pacific economic ecosystem.

The purpose of this paper is to examine the relationship between corporate financial health, as measured by the Altman Z-Score (Altman, 1968), and corporate performance, as measured by the Return on Equity (ROE), of listed manufacturing companies on the Hong Kong Stock Exchange (HKSE or SEHK) which is the largest exchange in Hong Kong. More specifically, we seek to determine whether financial health is a determinant of corporate performance in this market.

\subsection{Motivation \& Contribution}

Corporate performance is important but sound financial health is also needed to ensure sustainability. The motivation of this study is to determine whether well performing companies are financially healthy in this market. This study extends the work by Meric, Lents, Li and Meric (2014) on the Asia Pacific markets by providing further understanding into the financial health, as measured by the Z-Score, and corporate performance, as measured by ROE.

An important contribution is to provide empirical insights about this market in relation to its firms' Z-Score and ROE over a period of five years, i.e. 2013 to 2017 (inclusive). This study also provides an examination of the trends of ZScores over time (mean, median and standard deviation). We believe this study would contribute to the further understanding of this market by key stakeholders, such as investors.

With Asia's growing economic importance, the study hopes to serve as catalyst for similar research on other Asian economies. Additionally, a further motivation has been to extend and update the authors' previous works on this subject (Foo, 2015). 


\subsection{Literature Review}

Corporate financial health has been widely studied on countries in the Asia Pacific. These studies include Hong Kong and Singapore (Foo, 2015), China (Wang and Campbell, 2010A and 2010B), India (Pradhan, 2014), Sri Lanka (Gunathilaka, 2014), and Malaysia (Thai, Goh, Teh, Wong and Ong, 2014). The Altman Z-Score (Altman, 1968) was the preferred measure of financial health in these studies.

Unlike the prior model by Beaver (Beaver, 1966) which examined financial ratios separately, Edward I. Altman, created the Altman Z-Score (Altman, 1968) which combined a variety of financial ratios into a single score that reflected the likelihood of a firm going into bankruptcy using multiple discriminant analysis (MDA).

The model showed high predictive power on companies facing financial distress, as measured by the Z-Score. The literature on statistical models for bankruptcy prediction is wide-ranging and continues to expand. For example, E. I. Altman, in his lecture (Altman, 2007) quotes 12 new variants of his models. Other studies on financial health that followed the Z-Score Model include Blum (1974), Deakin (1977), Beynon and Peel (2001), Neophytou et al. (2001) and Chung et al. (2008). Some researchers also used logit regression techniques (Ohlson, 1980), recursive partitioning analysis (Frydman et al., 1985) and artificial neural network models (Trippi and Turban, 1996). Nevertheless, Perez (2006) highlighted that MDA is still one of the most popular approaches used for bankruptcy prediction (Agarwal and Taffler, 2007).

Furthermore, Aziz and Dar (2006) appraised 89 studies on prediction of bankruptcy between 1968 and 2003 and found that the multi-variable models, such as the Z-Score model, were the most widely accepted. Additionally, a significant body of research (e.g. Altman and McGough, 1974; Altman, 1982; Levitan and Knoblett, 1985; Koh and Killough, 1990) supports the reliability of the Z-Score for the prediction of financial distress. Recently, Sherbo and Smith's (2013) study concluded that the Z-Score model has stood the test of time and is still highly applicable in today's business environment. In view of the above merits, this study adopts the Altman Z-Score as our measure of financial health. The formula for the model is discussed in the Methodology and Data section of this paper.

There have been numerous measures of corporate performance and profitability. However, the Return on Equity (ROE) has proven to be a consistently robust and popular measure of corporate performance (Chen (1997), Chen (2005), Damodaran (2007), Hagel et al. (2010), and Zhao (2013)). ROE is defined as the income produced on equity capital and is calculated by dividing net income by the book value of shareholder's equity (Damodaran, 2007). It is a widely used accounting measure of companies' financial performance in making investment decisions (Stowe, Robinson, Pinto \& McLeavey, 2002). In view of this body of literature, we adopt ROE as our measure of corporate performance in this study.

A key comparative study done between Asia Pacific countries was by Meric, Lentz, Li and Meric (2014). This study examined the financial characteristics (liquidity, turnover ratios, financial leverage, profitability and growth) of manufacturing firms using multivariate analysis. Although it provided useful insights into these markets, this study did not explore the relationship between their corporate performance and their financial health.

A recent study by Tandiontong and Mathius (2017), found the partial correlation between stock returns and Altman Z-Score, beta stocks and inflation in the Indonesian stock market. Another recent study by Saji (2018) showed that the Zscores of firms carry sufficient information content that forewarns their stock market failures two to five years in advance (Indian realty sector).

\subsection{Research Question \& Hypothesis}

The research question for study is: do higher performing listed manufacturing companies (as measured by the ROE dependent variable) in the market also exhibit higher financial health (as measured by the Altman Z-Score - independent variable)? The Null Hypothesis is that there is no significant statistical relationship between firm performance and financial health in each market. Whereas, the Alternative Hypothesis is that there is a significant statistical relationship between firm performance and financial health. 


\section{METHOD}

\subsection{Methodology \& Data}

This study adopts the widely used Altman (1968) Z-Score model (Wang and Campbell, 2010A and 2010B; Pradhan, 2014; Gunathilaka, 2014; Thai, Goh, Teh, Wong and Ong, 2014) to determine financial health. The Z-Score formula is provided in Figure 1.

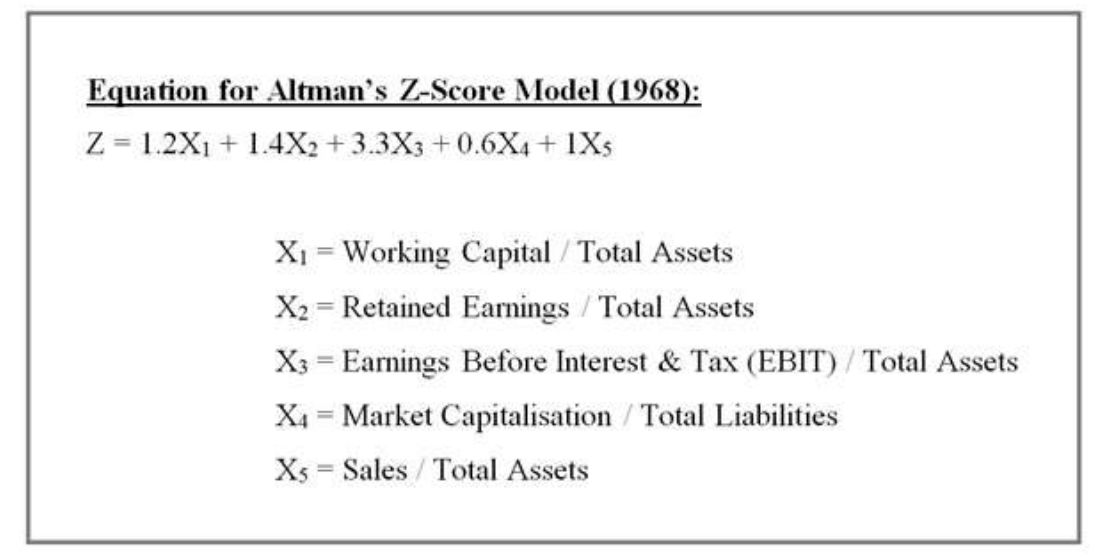

Figure 1: Equation for Altman's Z-Score Model (1968).

A linear regression was run using the relevant data with this formula: $\mathrm{Y}=\beta 1 \mathrm{Z} 1+\mathrm{C}$ where $\mathrm{Y}$ is the dependent variable, which is the Return on Equity (ROE); $\beta 1$ is the regression coefficient, which provides an indication of the direction and magnitude of the relationship; Z1 is the independent variable which is the Altman Z-Score and $\mathrm{C}$ is the constant.

The scope of the regression covers the period from 2013 to 2017. The financial statement data used was extracted from the Thomson Reuters DataStream database. Records of all firms listed on the two exchanges that had available error-free information were utilized in the regression analysis. Furthermore, the top and bottom $1 \%$ of the outliers were removed for the regression analysis. 


\section{RESULTS}

\subsection{Descriptive Analysis}

Table 1: Mean and Median Z-Scores - Hong Kong (HKSE).

\begin{tabular}{|l|r|r|r|r|r|}
\hline Year & \multicolumn{1}{|c|}{$\mathbf{2 0 1 3}$} & \multicolumn{1}{c|}{$\mathbf{2 0 1 4}$} & \multicolumn{1}{c|}{$\mathbf{2 0 1 5}$} & \multicolumn{1}{c|}{$\mathbf{2 0 1 6}$} & \multicolumn{1}{c|}{$\mathbf{2 0 1 7}$} \\
\hline Median & 2.38 & 2.26 & 2.35 & 2.21 & 2.22 \\
\hline Mean & 3.33 & 3.44 & 3.87 & 4.10 & 3.44 \\
\hline Std. Dev. & 5.53 & 7.58 & 7.78 & 16.50 & 7.70 \\
\hline
\end{tabular}

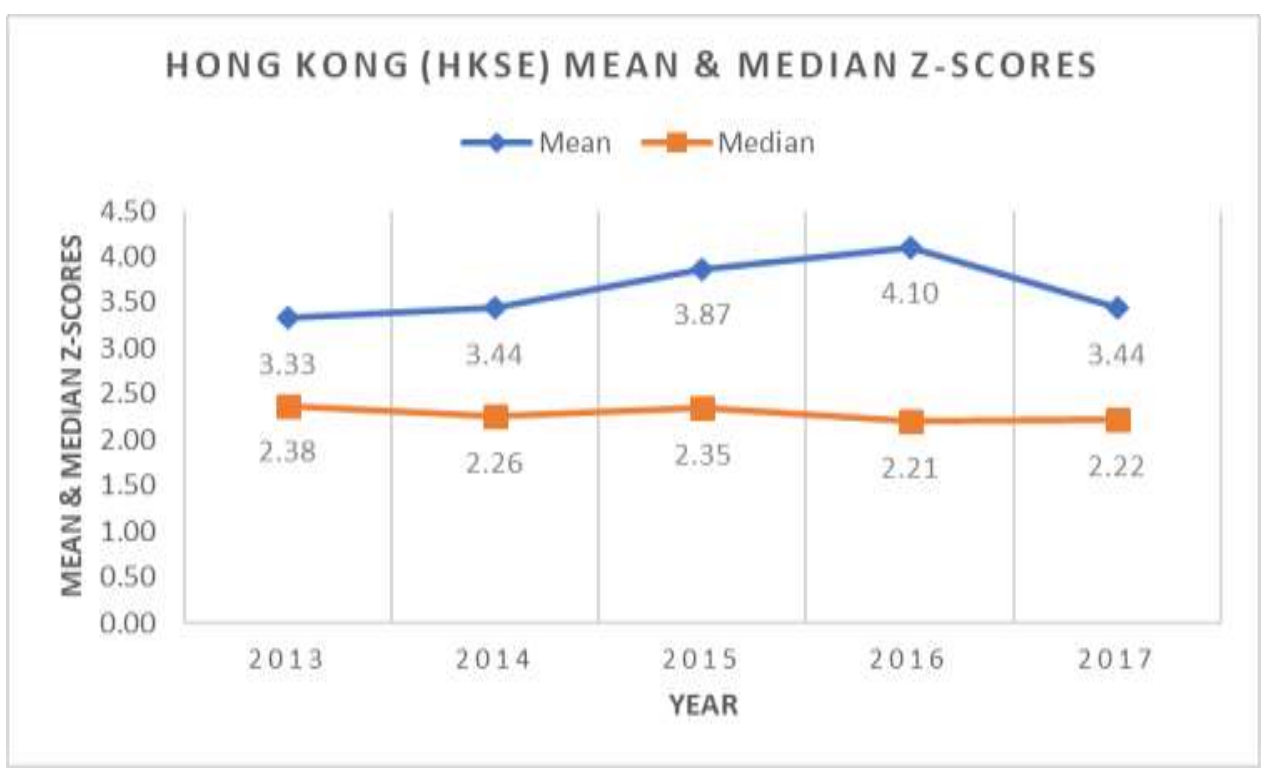

Figure 2: Mean and Median Z-Score Trends for Hong Kong (HKSE).

Table 1 above presents the mean and median Z-Scores (with standard deviations) for the market and Figure 2 above presents the respective trends for the five-year period from 2013 to 2017.

As per Altman (1968), a Z-Score that is greater than 2.99 indicates strong financial health, as shown in green in the tables. Whereas, a Z-Score that is lower than 1.81 indicates poor financial health.

The overall means and median Z-Scores are in the moderate-to-healthy range throughout the period. This indicates that generally, the market is financially healthy, which is also aligned with its economic standings in the Asia Pacific region.

The median Z-Scores are considerably lower in magnitude than their mean Z-Scores throughout the period. This could be explained by the large variations in the size and type of firms. The median Z-Scores stayed relatively constant from 2013 to 2017, whilst the means rose till 2016 after which they fell until 2017.

Additionally, the market's mean Z-Scores have remained within the range of 3.33 to 4.10 and its median scores ranged from 2.21 to 2.38. During the five-year period, the mean Z-Scores exceeded the higher 2.99 benchmark in all five years. This presents a strong financial health outlook for the market. 


\subsection{Regression Analysis}

Table 2: Statistical Regression Outputs - Hong Kong (HKSE).

\begin{tabular}{|c|c|c|c|c|c|c|}
\hline & Coefficients & $\begin{array}{l}\text { Standard } \\
\text { Error }\end{array}$ & t Stat & $\begin{array}{c}\text { P- } \\
\text { value }\end{array}$ & Lower $95 \%$ & $\begin{array}{c}\text { Upper } \\
95 \%\end{array}$ \\
\hline Z-Scores & 1.5420 & 0.6774 & 2.2761 & 0.0229 & 0.2137 & 2.8702 \\
\hline
\end{tabular}

A total of 3,676 observations have been used for the regression of firms in the HKSE (see Table 2). Based on these observations, it has a regression coefficient of 1.542 (rounded). The standard error is close enough to zero, at 0.677 , whilst the t-statistic is significant and positive at 2.2761 and the p-value is equal to 0.023 , supporting the reliability of the regression output. This result confirms the Alternative Hypothesis by showing a positive (direction) and significant (magnitude) relationship between ROE, the dependent variable (representing corporate performance), and Z-Score, the independent variable (representing financial health).

Overall, these results show that there is indeed a statistically significant and positive relationship between firm performance and financial health in the stock exchange. These strong positive and significant relationships between corporate performance and financial health may be construed as a positive signal for business stakeholders such as investors in this market.

\section{DISCUSSION}

\subsection{Limitations}

A limitation of this study is that it focuses on listed manufacturing corporations, and not on other industries. This is because we would like to align our approach with the original Altman (1968) Z-Score Model. The focus of this paper is to explore the relationships of financial health and corporate performance in the specific contexts of the chosen market.

\subsection{Future Research}

For future research, the proposed methodology can be applied to analyse the relationship between financial health and corporate performance in other markets across Asia and beyond. Other industries can be included to enhance the breadth and depth of the study. Furthermore, other variables can also be examined, and their relationships analysed.

\subsection{Conclusion}

We set out to explore and analyse the relationship between financial health, as measured by the Altman (1968) ZScore, and firm performance, as measured by Return on Equity (ROE) ratios, of manufacturing companies listed in Hong Kong's HKSE. We found that there was a statistically significant and positive relationship between Return on Equity (ROE) and Altman Z-Scores in the market. Furthermore, in our descriptive analysis, we observed generally moderate-tohealthy mean and median Z-Scores in the market and similar mean and median Z-Score trends over the period. These relationships may be construed as a positive assurance for stakeholders in this market, such as investors.

From an academic contribution standpoint, this study provides an updated empirical insight into the relationship between financial health and financial performance of listed companies in Hong Kong using recent data from 2013 to 2017. More importantly, with the growing importance of Hong Kong in the global economic landscape, key stakeholders can gain further understanding and assurance on the state of the market's firms' current financial health and performance. 


\section{REFERENCES}

[1] Agarwal, V., \& Taffler, R. J. (2007). Twenty-five years of the Taffler z-score model: Does it really have predictive ability? Accounting and Business Research, 37(4), 285-300. http://dx.doi.org/10.1080/00014788.2007.9663313

[2] Altman, E. I. (1968) a. Financial Ratios, Discriminant Analysis and The Prediction Of Corporate Bankruptcy. The Journal of Finance, 23(4), 589-609. http://dx.doi.org/10.1111/j.1540-6261.1968.tb00843

[3] Altman, E. I. (1982) b. Accounting implications of failure prediction models. The Journal of Accountancy, 6(1), 419.

[4] Altman, E. I. (2007) c. Revisiting credit scoring models in a Basel 2 environment. Lecture at National Taiwan University. [Online] Available: www.fin.ntu.edu.tw/ hwangdar/94emba19.ppt

[5] Altman, E. I., \& McGough, T. P. (1974). Evaluation of a company as a going-concern. The Journal of Accountancy, $143,50-57$.

[6] Aziz, M. A., \& Dar, H. A. (2006). Predicting corporate bankruptcy: where we stand? Corporate Governance, 6(1), 18-33. http://dx.doi.org/10.1108/14720700610649436

[7] Beaver, W. H. (1966). Financial ratios as predictors of failure. Journal of Accounting Research, 4, 71 - 111. http://dx.doi.org/10.2307/2490171

[8] Beynon, M. J., \& Peel, M. J. (2001). Variable precision rough set theory and data discretization: An application to corporate failure prediction. Omega, 29, 561-576. http://dx.doi.org/10.1016/S0305-0483(01)00045-7

[9] Blum, M. P. (1974). Failing company discriminant analysis. Journal of Accounting Research, 12(1), 1-25. http://dx.doi.org/10.2307/2490525

[10]BSE India. (2016). Introduction: BSE India. BSE India. [Online] Available: http://www.bseindia.com/static/about/introduction.aspx?expandable =0

[11] Calandro Jr, J. (2007). Considering the utility of Altman's Z-score as a strategic assessment and performance management tool. Strategy \& Leadership, 35(5), 37-43. http://dx.doi.org/10.1108/10878570710819206

[12] Cendrowski, S. (2015). China's Global 500 companies are bigger than ever-and mostly state-owned. Fortune. [Online] Available: http://fortune.com/2015/07/22/china-global-500-government-owned/

[13] Chen, M. C., Cheng, S. J., \& Hwang, Y. (2005). An empirical investigation of the relationship between intellectual capital and firms' market value and financial performance. Journal of Intellectual Capital, 6(2), 159-176. http://dx.doi.org/10.1108/14691930510592771

[14] Chen, S., \& Dodd, J. L. (1997). Economic Value Added (EVA'M): An Empirical Examination Of A New Corporate Performance Measure. Journal of Managerial Issues, 9(3), 318-333.

[15] Chung, K. C., Tan, S. S., \& Holdsworth, D. K. (2008). Insolvency prediction model using multivariate discriminant analysis and artificial neural network for the finance industry in New Zealand. International Journal of Business and Management, 3(1), 19-29.

[16] Damodaran, A. (2007). Return on Capital (ROC), Return on Invested Capital (ROIC) and Return on Equity (ROE): Measurement and Implications. Stern School of Business, 2-66. http://dx.doi.org/10.2139/ssrn.1105499

[17]Deakin, E. B. (1977). Business failure prediction: An empirical analysis. In E. Altman, \& A. Sametz (Eds.), Financial crises: Institutions and markets in a fragile environment. New York: John Wiley.

[18]Foo, S. L. (2015). Financial Health \& Corporate Performance of Listed Manufacturing Companies in Hong Kong \& Singapore: A Comparative Study of the Two Asian Tigers. Asian Journal of Business and Management, 3(2), 148$154 . \quad$ [Online] Available: http://www.ajouronline.com/index.php?journal=AJBM\&page=article\&op=view\&path\%5B\%5D=2451

[19] Frydman, H. E., Altman, E. I., \& Kao, D. G. (1985). Introducing Recursive Partitioning for Financial Classification: The Case of Financial Distress. Journal of Finance, 40(1), 269-291. http://dx.doi.org/10.1111/j.15406261.1985.tb04949.x

[20] Gunathilaka, C. (2014). Financial Distress Prediction: A Comparative Study of Solvency Test and Z-Score Models with Reference to Sri Lanka. The IUP Journal of Financial Risk Management, 11(3), 39-51.

[21] Hagel, J., \& D, J. (2010). The Best Way to Measure Company Performance. Harvard Business Review. [Online] Available: https://hbr.org/2010/03/the-best-way-to-measure-compan.html

[22] IndexMundi. (2013). China vs. India: Country Comparisons. IndexMundi. [Online] Available: http://www.indexmundi.com/factbook/compare/china.india/economy

[23] International Monetary Fund (IMF). (2017). October 2017: Making the Most of the Upswing. Regional Economic Outlook. [Online] Available: https://www.imf.org/en/Publications/REO/APAC/Issues/2017/10/09/areo1013

[24] Koh, H. C., \& Killough, L. N. (1990). The use of multiple discriminant analysis in the assessment of the going concern status of an audit client. Journal of Business Finance \& Accounting, 17(2), 179-192. http://dx.doi.org/10.1111/j.1468-5957.1990.tb00556.x

[25] Levitan, A. S., \& Knoblett, J. A. (1985). Indicators of exceptions to the going concern assumption. Auditing: A Journal of Practice and Theory (Fall), 26-39.

[26] Meric, I., Lentz, C., Li, S., \& Meric, G. (2014). A Comparison of the Financial Characteristics of Hong Kong and Singapore Manufacturing Firms. Global Journal of Business Research, 8(3), 31-37. 
[27] Monaghan, A. (2014). China surpasses US as world's largest trading nation. The Guardian. [Online] Available:http://www.theguardian.com/business/2014/jan/10/china-surpasses-us-world-largest-trading-nation

[28] Neophytou, E., Charitou, A., \& Charalambous, C. (2001). Predicting corporate failure: Empirical evidence for the UK. Discussion Paper No. 01-173, March, School of Management, University of Southampton, Southampton.

[29] Ohlson, J. (1980). Financial Ratios and the Probabilistic Prediction of Bankruptcy. Journal of Accounting Research, 18(1), 109-131. http://dx.doi.org/10.2307/2490395

[30] Perez, M. (2006). Artificial neural networks and bankruptcy forecasting: a state of the art. Neural Computer \& Application, 15, 154-163. http://dx.doi.org/10.1007/s00521-005-0022-x

[31] Pradhan, R. (2014). Z Score Estimation for Indian Banking Sector. International Journal of Trade, Economics and Finance, 5(6), 516-520. http://dx.doi.org/10.7763/IJTEF.2014.V5.425

[32] Saji, T.G. (2018). Financial Distress and Stock Market Failures: Lessons from Indian Realty Sector. Vision 22(1), 50-60. http://dx.doi.org/10.1177\%2F0972262917750244

[33] Shanghai Stock Exchange (SSE). (2015). Brief Intro: Shanghai Stock Exchange (SSE). Shanghai Stock Exchange (SSE). [Online] Available: http://english.sse.com.cn/aboutsse/sseoverview/brief/

[34] Sherbo, A., \& Smith, A. (2013). The Altman Z-Score Bankruptcy Model at Age 45: Standing the Test of Time? ABI Journal, 32(11), 40-42.

[35] Stowe, J. D., Robinson, T. R., Pinto, J. E., \& McLeavey, D. W. (2002). Analysis of Equity Investments: Valuation (pp. 55-58). Association for Investment Management and Research (AIMR).

[36] Thai, S., Goh, H., Teh, B., Wong, J., \& Ong, T. (2014). A Revisited of Altman Z- Score Model for Companies Listed in Bursa Malaysia. International Journal of Business and Social Science, 5(12), 197-207.

[37] Tandiontong, M., Mathius, M. (2017). The Influence of Financial Distress Using Altman Z-Score, the Beta of Stocks and Inflation to the Stock Return. Journal of Finance and Banking Review, Vol. 2(2), p. 21-27, Apr-Jun 2017. [Online] Available: https://ssrn.com/abstract=3000747

[38] Trippi, R. R., \& Turban, E. (1996). Neural networks in finance and investing: using artificial intelligence to improve real-world performance. (pp. 367-394). London: IRWIN Professional Publishing, 367-394.

[39] Wang, Y., \& Campbell, M. (2010). Business Failure Prediction For Publicly Listed Companies In China. Journal of Business and Management, 16(1), 75-88.

[40] Wang, Y., \& Campbell, M. (2010). Do Bankruptcy Models Really Have Predictive Ability? Evidence Using China Publicly Listed Companies. International Management Review, 6(2), 77.

[41] World Bank. (2018). Annual GDP Growth (\%). [Online] Available: https://data.worldbank.org/country/india?view=chart

[42] World Federation of Exchanges. (2015). Monthly Reports. World Federation of Exchanges. [Online] Available: http://www.world-exchanges.org/home/index.php/statistics/monthly-reports

[43] Zhao, Y. (2013). The Relationship between Share Price Gains, Corporate Performance and Risk. OALib Journal, 110-112. [Online] Available: http://www.oalib.com/paper/2993772 